\title{
GLP-1 based therapeutics: simultaneously combating T2DM and obesity
}

\author{
Kristy M. Heppner ${ }^{1}$ and Diego Perez-Tilve ${ }^{2 *}$ \\ ${ }^{1}$ Division of Diabetes, Obesity and Metabolism, Oregon National Primate Research Center, Oregon Health and Science \\ University, Beaverton, OR, USA, ${ }^{2}$ Department of Medicine, Metabolic Diseases Institute, University of Cincinnati, Cincinnati, \\ $\mathrm{OH}, \mathrm{USA}$
}

OPEN ACCESS

Edited by:

Marc Claret

Institut d'Investigacions Biomèdiques August Pi i Sunyer, Spain

Reviewed by:

Joao Carlos Dos Reis Cardoso, University of Algarve, Portugal Denise D. Belsham,

University of Toronto, Canada

${ }^{*}$ Correspondence:

Diego Perez-Tilve

College of Medicine/Internal Medicine, Metabolic Disease Institute, University of Cincinnati, 2180 E. Galbraith Road

A-125, Cincinnati, OH 45220, USA pereztdo@ucmail.uc.edu

Specialty section:

This article was submitted to Neuroendocrine Science, a section of the journal Frontiers in Neuroscience

Received: 07 February 2015 Paper pending published: 19 February 2015 Accepted: 05 March 2015 Published: 20 March 2015

Citation:

Heppner KM and Perez-Tilve D (2015) GLP-1 based therapeutics: simultaneously combating T2DM and obesity. Front. Neurosci. 9:92. doi: 10.3389/fnins.2015.00092
Glucagon-like peptide-1 (GLP-1) enhances meal-related insulin secretion, which lowers blood glucose excursions. In addition to its incretin action, GLP-1 acts on the GLP-1 receptor (GLP-1R) in the brain to suppress feeding. These combined actions of GLP-1R signaling cause improvements in glycemic control as well as weight loss in type II diabetes (T2DM) patients treated with GLP-1R agonists. This is a superior advantage of GLP-1R pharmaceuticals as many other drugs used to treat T2DM are weight neutral or actual cause weight gain. This review summarizes GLP-1R action on energy and glucose metabolism, the effectiveness of current GLP-1R agonists on weight loss in T2DM patients, as well as GLP-1R combination therapies.

Keywords: GLP-1, obesity, diabetes, CNS, insulin

\section{Introduction}

Obesity is a global health problem and increases the risk of developing type II diabetes mellitus (T2DM), cardiovascular disease, and dyslipidemia. These metabolic complications caused by obesity result in a decreased lifespan (Fontaine et al., 2003; Olshansky et al., 2005). The cost of treating obesity-related diseases has reached epic proportions and is estimated to cost \$147 billion in the US alone (Finkelstein et al., 2009). Many treatments approved for T2DM treatment such as sulphonylureas and thiazolidinediones (TZDs) improve glucose metabolism but have the unwanted side effect of causing weight gain (Thule and Umpierrez, 2014) and (Kahn et al., 2006; Home et al., 2009; Ryan et al., 2011). As the majority of patients with T2DM are also obese, medications that exacerbate weight gain are not ideal. Moreover, small reductions in body weight alone can have beneficial effects on blood pressure as well as glucose and cholesterol metabolism (Klein et al., 2004; Wing et al., 2011). Therefore, therapies that promote weight loss and simultaneously improve glucose metabolism are superior treatments for obese patients with T2DM.

Glucagon-like peptide-1 (GLP-1) is a gastrointestinal hormone as well as a neurotransmitter. GLP-1 was initially discovered for its ability to enhance glucose-stimulated insulin secretion (GSIS) (Kreymann et al., 1987; Mojsov et al., 1987). Shortly after this, it was demonstrated that GLP-1 suppresses food intake through CNS-mediated mechanisms (Turton et al., 1996; TangChristensen et al., 1998). Consistent findings have shown that GLP-1R agonism promotes weight loss and improves glucose homeostasis in rodents, monkeys and humans (reviewed in Barrera et al., 2011a). This dual action has made GLP-1 analogs superior therapeutics for the treatment of T2DM. 


\section{The Anatomical Distribution of the Endogenous GLP-1 System}

GLP-1 is derived from the preproglucagon gene. In the periphery, posttranslational processing of preproglucagon in the alpha-cells of the pancreas produces glucagon and a small amount of GLP-1 whereas the main source of peripheral GLP-1 production occurs through the posttranslational processing of preproglucagon in the L-cells of the gut (reviewed in Holst, 2007 and Campbell and Drucker, 2013). The GLP-1R is located in a number of peripheral tissues including the pancreas, gastrointestinal tract, kidney, lung and heart (Thorens, 1992; Bullock et al., 1996; Pyke et al., 2014). The GLP-1R is a class B1 G-protein coupled receptor that predominately couples to a $\mathrm{G} \alpha_{s}$ subunit leading to the activation of adenylyl cyclase (Kirkpatrick et al., 2012; Willard and Sloop, 2012).

In the brain, preproglucagon expressing neurons are localized to the brainstem in regions including the nucleus of the solitary tract (NTS) and ventrolateral medulla (Merchenthaler et al., 1999) and these neurons produce a number of peptides including GLP-1, oxyntomodulin, and glucagon-like peptide-2 (Holst, 2007). CNS preproglucagon distribution is similar in rodents, monkeys, and humans (Merchenthaler et al., 1999; Vrang and Grove, 2011; Zheng et al., 2015). Brainstem preproglucagon expressing fibers project to many areas of the brain with the most abundant projections to areas hypothalamic areas that control energy homeostasis including the arcuate nucleus (ARC), paraventricular nucleus (PVN), and dorsomedial nucleus (DMH) (Jin et al., 1988). The distribution of the GLP-1R is similar to preproglucagon fiber projections with high expression in hypothalamic areas that regulate energy homeostasis, both in rodents and non-human primates (Merchenthaler et al., 1999; Heppner et al., 2015).

\section{GLP-1R-Mediated Action on Glucose Metabolism: Peripheral vs. CNS Actions}

GLP-1R signaling plays a critical role in the maintenance of glucose homeostasis as deletion of the GLP-1R in mice results in impaired glucose tolerance (Scrocchi et al., 1996) and physiological levels of GLP-1 enhance meal-related insulin secretion in humans (Kreymann et al., 1987; Mojsov et al., 1987). Although it is well established that the endogenous GLP-1R system is essential for glycemic control, the specific GLP-1R population that mediates this effect is still a matter of debate. In the periphery, GLP-1 acts directly on pancreatic islets to enhance GSIS (Mojsov et al., 1987) and inhibit glucagon release (Komatsu et al., 1989). A study in transgenic animals demonstrates that selectively restoring pancreatic GLP-1Rs in GLP-1R null mice normalizes glucose tolerance in these animals suggesting that GLP- $1 \mathrm{R}$ expression in the pancreas is sufficient to maintain normal glucose metabolism (Lamont et al., 2012). In contrast, another study demonstrated that transgenic mice with a beta-cell specific deletion of the GLP$1 \mathrm{R}$ have impaired intraperitoneal (ip) glucose tolerance but maintain normal oral glucose tolerance (Smith et al., 2014). These data demonstrate that GLP-1R signaling in the beta cells reduces hyperglycemia but other GLP-1Rs, possibly on neural tissue, are involved in mediating the incretin action of GLP-1.

In addition to this direct control of beta cells, GLP-1R signaling plays a role in the control of glucose homeostasis by regulating the activity of neurons both in the peripheral and central nervous system. Thus, blockade of hepatic portal GLP-1R signaling causes glucose intolerance in rats, suggesting that GLP-1Rs located on nerve terminals in the hepatic portal vein contribute to the incretin action of GLP-1 (Vahl et al., 2007). Furthermore, GLP-1 stimulates preganglionic vagal neurons projecting to the pancreas (Wan et al., 2007), raising the possibility that this mechanism may contribute to GLP-1 stimulation of insulin secretion.

Rodent studies involving pharmacological manipulation of GLP-1R in the brain by intracerebroventricular (ICV) administration of agonists and antagonists demonstrate a role for brain GLP-1R signaling in the control of glucose metabolism. However, this regulation appears to be complex, likely as a result of the contribution of multiple sites throughout the CNS that target distinct elements in peripheral tissues that play a role in the control of glucose homeostasis. For instance, central administration of GLP-1R agonists increases the ability of insulin to suppress endogenous glucose production (Knauf et al., 2005; Sandoval et al., 2008; Burmeister et al., 2012). Interestingly, this occurs despite a reduction in glucose uptake in muscle (Knauf et al., 2005), which is consistent with the increased muscle glucose uptake exhibited by mice lacking GLP-1R expression (Ayala et al., 2009). The complexity of the contribution of CNS-GLP-1R to the control of glucose homeostasis is accentuated by marked interspecies differences. For example, chronic ICV infusion of the GLP-1R antagonist exendin-9 impairs glucose tolerance in rats, supporting a role for CNS GLP-1R signaling in the maintenance of glycemic control (Sandoval et al., 2008; Barrera et al., 2011b). In contrast, another study in rats demonstrated that acute injection of the GLP-1R agonist exendin-4 (Ex-4) increases baseline glucose levels in rats which is due to the activation of the sympathetic nervous system (Perez-Tilve et al., 2010). These data indicate that GLP-1R signaling regulates the activity of different neuronal populations involved in the control of specific aspects contributing to glucose homeostasis. However, recent evidence demonstrates that this regulation may not be necessary for the maintenance of whole body glucose metabolism, at least in mice. Hence, mice lacking GLP-1R only in the peripheral nervous system (PNS) or central nervous system have normal ip and oral glucose tolerance as compared to controls (Sisley et al., 2014). Furthermore, chronic treatment with the GLP-1 mimetic liraglutide induces similar improvements on glucose tolerance despite the loss of PNS or CNS-GLP-1R expression, indicating that non-neuronal GLP-1R signaling is sufficient for the long-term improvements in glucose homeostasis induced by liraglutide in mice (Sisley et al., 2014).

\section{The Endogenous GLP-1 System in the Regulation of Energy Homeostasis}

The endogenous GLP-1 system is densely populated in areas that control energy homeostasis placing it in the neuroanatomical 
position to regulate food intake and body weight. GLP-1 producing neurons in the brainstem are activated following a large satiating meal suggesting that these neurons relay satiety signals to higher brain regions (Kreisler et al., 2014). Knockdown of preproglucagon expression in the hindbrain as well as central GLP$1 \mathrm{R}$ antagonism results in hyperphagia and body weight gain in rats indicating that these neurons are essential for maintenance of normal body weight (Barrera et al., 2011b). Global knockout of the GLP-1R produces no body weight or food intake phenotype in chow-fed mice (Scrocchi et al., 1996). However, when these mice are placed on a high-fat diet (HFD) the Glp1r-/animals are leaner than wild-type (WT) controls (Hansotia et al., 2007; Wilson-Perez et al., 2013), a phenotype that goes against the role of GLP-1R signaling in the control of body weight. However, the GLP-1R is also involved in adipogenesis in the periphery, which may account for this discrepancy (Challa et al., 2012). To further dissect the role of the endogenous CNS GLP-1R system, conditional CNS specific knockout models were created. Similar to global Glp1r-/- mice, animals with deletion of the GLP-1R in vagal afferent/efferent nerves, Phox $2 b$-Cre Glp1 $r^{f l o x} / f l o x$, as well as animals with a deletion of the GLP-1R in the CNS, nestin-Cre Glp $1 r^{\text {flox/flox }}$, maintain a similar body weight and food intake as control mice on both chow and HFD (Sisley et al., 2014). These findings challenge whether endogenous PNS or CNS GLP-1R signaling is essential for maintaining normal energy homeostasis. Again, these discrepancies in the literature investigating the role of GLP-1R signaling in the control of energy homeostasis could be partially due to mammalian species differences, mice vs. rats, or differences in methodologies used to manipulate GLP-1R signaling.

\section{Pharmacological Effects of GLP-1R Agonism on Energy Homeostasis}

Despite controversial findings over the role of the endogenous GLP-1 system in maintaining energy homeostasis, consistent findings demonstrate that pharmacological administration of GLP-1R agonists suppresses body weight across a number of species. The specific sites of action and underlying molecular mechanisms that mediate GLP-1R-induced body weight loss are currently being investigated. Here, we review mechanisms by which GLP-1R agonists reduce body weight.

\section{GLP-1R Regulation of Food Intake}

The reduction in body weight induced by GLP-1R agonists is largely attributed to a reduction in food intake. However, the specific sites that are involved in mediating GLP-1R induced hypophagia are not completely understood. Rats receiving vagotomy do not reduce food intake in response to peripherally injected GLP-1 indicating that vagal afferent nerves are needed to relay peripheral GLP-1 signals to higher brain regions to regulate feeding (Abbott et al., 2005). In contrast, another group demonstrated that peripheral administration of either liraglutide or Ex-4 induced a reduction in food intake in both control rats as well as rats that have had subdiaphragmatic vagal deafferentation (Kanoski et al., 2011). However, higher doses of liraglutide and
Ex-4 were necessary in rats with subdiaphragmatic vagal deafferentation suggesting that vagal afferent neurons contribute to the suppression of food intake induced by peripherally administered GLP-1R mimetics but other brain regions are also involved in mediating this action (Kanoski et al., 2011). Another study used a genetic loss of function mouse model to delete the GLP-1R in vagal afferent/effect nerves (Phox $2 b$-Cre Glp 1 flox/flox $^{\text {) }}$ (Sisley et al., 2014). This study showed that chronic peripheral administration of liraglutide to Phox $2 b$-Cre Glp 1 flox/flox mice fed a HFD reduced food intake, body weight, and adiposity suggesting that the PNS is not required for liraglutide to mediate its effects on energy metabolism. Together these data indicate that although vagal afferent neurons may contribute to hypophagia induced by peripheral administration of GLP-1R analogs, these neurons are not necessary for the hypophagic effect.

It is evident that CNS GLP-1R signaling is essential for mediating the pharmacological action of GLP-1R agonists on energy metabolism as genetic deletion of CNS GLP-1R signaling in mice ablates the action of peripherally administered liraglutide on food intake and body weight reduction (Sisley et al., 2014). However, the specific brain regions that mediate these actions are not fully understood. The hindbrain has been implicated in mediating GLP-1R effects on food intake. Rats receiving brainstemhypothalamic transection do not have a reduction in food intake in response to peripherally administered GLP-1 which suggests that the brainstem plays a critical role in communicating peripheral satiety signals to higher brain centers (Abbott et al., 2005). Furthermore, ICV injection of Ex-4 into the 4 th ventricle of rats causes a suppression of food intake (Hayes et al., 2011). The specific brain regions in the hindbrain that mediate GLP-1R mediated suppression of food intake are currently being examined. The lateral parabrachial nucleus may be a critical site of action as pharmacological activation of GLP-Rs in the lateral parabrachial nucleus (LPBN) inhibits feeding whereas antagonism of LPBN GLP-1Rs induces hyperphagia (Alhadeff et al., 2014).

The hypothalamus has also been implicated as a major center for mediating the pharmacological effects of GLP-1R action on energy metabolism. More specifically, the ARC nucleus of the hypothalamus has been highlighted as one of the main sites mediating this action as chemical lesion of the ARC in rats ablates the anorectic action of GLP-1 (Tang-Christensen et al., 1998). Peripherally administered liraglutide has recently been shown to gain access into certain areas of the brain with the majority entering the ARC and median eminence with smaller amounts in the PVN (Secher et al., 2014). Animals that lack the GLP-1R do not show evidence of liraglutide in the ARC suggesting that peripherally administered liraglutide requires the GLP-1R to enter into the CNS (Secher et al., 2014). The specific neuronal populations in the ARC that mediate the anorectic action of GLP-1R signaling are currently being investigated. Much evidence suggests that activation of anorexogenic proopiomelanocortin (POMC) neurons and simultaneous inhibition of orexigenic neuropeptide Y/Agouti-related peptide (NPY/AgRP) neurons in the ARC appears to be one of the major mechanisms for GLP-1R mediated inhibition of food intake. In support of this, ICV administration of GLP-1 in rats has been shown to attenuate the fasting-induced rise in NPY/AgRP expression and 
decreases fasting-induced inhibition of POMC/CART expression in the ARC (Seo et al., 2008). Similarly, ICV injection of Ex-4 increased c-fos expression in alpha-melanocyte stimulating hormone (alpha-MSH)-immunoreactive neurons in the ARC of mice (Dalvi et al., 2012). In line with these data, the GLP$1 \mathrm{R}$ has been found to be co-expressed in ARC POMC neurons in both rats (Sandoval et al., 2008) and mice (Ronnekleiv et al., 2014) suggesting that GLP-1 can act directly on these neurons. Electrophysiological recordings support this notion and have demonstrated that GLP-1 directly stimulates POMC/CART cells, whereas GLP-1 can also inhibit orexigenic NPY/AgRP cells in the ARC through an indirect mechanism (Secher et al., 2014). Consistent with these findings, it has been demonstrated that the GLP-1R agonist Ex-4 (Ronnekleiv et al., 2014) excites ARC POMC neurons in mice. Taken together, the data in the literature indicate that GLP-1R signaling in ARC may be a major contributor to the homeostatic effects of GLP-1 analogs on feeding, whereas other brain regions such as the brainstem may play a minor role.

\section{GLP-1R Mediated Effects on Visceral IIIness}

Much debate exists around whether the suppression of feeding induced by GLP-1 and GLP-1 mimetics is solely a homeostatic effect. GLP-1 administration induces visceral illness in both rodents (Seeley et al., 2000) and humans (Madsbad et al., 2008). It is clear that the CNS is necessary for GLP-1R mediated induction of visceral illness as mice with a CNS deletion of the GLP-1R develop conditioned taste aversion (CTA) to lithium chloride but not to liraglutide (Sisley et al., 2014). The exact brain region mediating this action is still under investigation. Injection of GLP-1 directly into the central nucleus of the amygdala (CeA) of rats results in CTA (Kinzig et al., 2002) whereas injection into the PVN reduces food intake without eliciting CTA (McMahon and Wellman, 1998). However, other studies in rats show that injection of Ex-4 into the medial subnucleus of the NTS produced CTA whereas injection into the CeA did not induce CTA (Kanoski et al., 2012). Whether the discrepancy in results of these studies is due to the use of native GLP-1 vs. Ex-4 is unclear. Further studies are necessary to understand the mechanisms involved in GLP-1R induction of visceral illness.

\section{GLP-1R Regulation of Food Reward}

In addition to being expressed in hypothalamic areas that regulate homeostatic feeding, the GLP-1R is expressed in areas that mediate food reward in both rodents (Merchenthaler et al., 1999) and non-human primates (Heppner et al., 2015). Consistent with the neuroanatomical location, functional studies support a role for GLP-1R signaling in regulating food reward. Direct injection of Ex-4 into the nucleus accumbens (NAc) or ventral tegmental area (VTA) reduces food reward without causing visceral illness (Dossat et al., 2011; Dickson et al., 2012). Peripheral administration of liraglutide decreased preference for highly palatable foods in rats suggesting that GLP-1R mimetics may have therapeutic potential to decrease food reward (Raun et al., 2007; Hansen et al., 2012). To further support a role for GLP-1R signaling in regulating food reward, recent $\mathrm{fMRI}$ studies in obese and obese T2DM patients have demonstrated that intravenous infusion of exenatide decreases the activation of brain regions involved in mediating food reward (van Bloemendaal et al., 2014).

\section{GLP-1R Action on Brown Adipose Tissue (BAT) Thermogenesis}

In addition to causing changes in feeding, central GLP-1R activation may regulate body weight by increasing brown adipose tissue (BAT) thermogenesis (reviewed in Lockie et al., 2013). Chronic ICV administration of oxyntomodulin, a GLP-1R agonist, in mice decreased body weight despite having no significant effects on food intake (Lockie et al., 2012). Interestingly, BAT temperature was increased in these animals, which may have contributed to the weight loss. The effect of oxyntomodulin on body weight and BAT temperature is not evident in mice that lack the GLP-1R highlighting a GLP-1R dependent action. To determine the site of GLP-1R mediated action on BAT thermogenesis, another group performed intranuclear injections of liraglutide and determined that the ventromedial nucleus of the hypothalamus (VMH) is the specific brain region that mediates GLP-1R-induced BAT thermogenesis (Beiroa et al., 2014). Furthermore, this effect involves hypothalamic AMPK inhibition as pharmacological and genetic activation of AMPK ablates the effect of liraglutide on BAT thermogenesis. The extent to which GLP-1R activation of BAT contributes to weight loss in humans is still a matter of debate. Many studies indicate that energy expenditure in humans treated chronically with GLP-1R agonists experience no change (Harder et al., 2004; Bradley et al., 2012) or a decrease in energy expenditure (van Can et al., 2014). However, another study reported that a group of T2DM patients treated with metformin plus liraglutide or metformin plus Ex-4 for 1 year experience an increase in resting energy expenditure compared to placebo treated controls when energy expenditure was adjusted for fat free mass (Beiroa et al., 2014). However, from the data provided in that study, it is not possible to determine the contribution of BAT thermogenesis to the reported increase in energy expenditure. Thus, although the increase in CNS-GLP-1R signaling is sufficient to activate BAT thermogenesis, whether this regulation is necessary for the contribution of BAT thermogenesis to the control of energy balance, or to the body weight lowering effects of GLP-1 based therapies still requires further investigation.

\section{GLP-1R Action on Neuroprotection}

GLP-1R analogs have neuroprotective and anti-inflammatory properties, which may be contributing the beneficial effects on energy metabolism (reviewed in Holscher, 2014). Studies in rodents have demonstrated that GLP-1R agonists reduce hippocampal cell death by reducing the development of amyloid- $\beta$ plaques (McIntyre et al., 2013). This neuroprotective action in hippocampal cells may be one of the mechanisms whereby GLP1R signaling enhances learning and memory in rodent studies (Oka et al., 1999; During et al., 2003; Abbas et al., 2009; McClean et al., 2010, 2011; Han et al., 2013). In addition to acting on hippocampal cells, chronic treatment with GLP-1 reduced degeneration of dopaminergic neurons in the substantia nigra and led to an improvement in motor function (Bertilsson et al., 2008; Harkavyi et al., 2008; Li et al., 2009). Although many preclinical studies suggest that GLP-1R agonism can act directly on neurons 
to prevent cell death, this neuroprotective property may be secondary to reduced glucotoxicity and inflammation in the brain that can result from weight loss and improvements in glycemic control (Berkseth et al., 2014).

\section{Effectiveness of GLP-1R Agonists on Weight Loss in Humans}

Despite not have a complete understanding of the underlying molecular mechanisms, GLP-1R activation clearly has beneficial effects on both energy and glucose metabolism across a number of species. Moreover, patients with T2DM have impaired incretin action, which highlights GLP-1 as a useful pharmacotherapy for restoring glucose control (reviewed in Madsbad, 2014). Unfortunately, GLP-1 is rapidly degraded by the enzyme dipeptidyl peptidase-4 (DPP-4), which limits the therapeutic efficacy of native GLP-1 (Deacon et al., 1995). Therefore, synthetic GLP1 analogs with resistance to degradation by DPP-4 were developed. There are currently two classes of GLP-1R analogs that are currently prescribed for the treatment of T2DM in humans: (1) GLP-1R agonists and (2) DPP-4 inhibitors (Drucker and Nauck, 2006).

\section{GLP-1R Agonists}

The GLP-1R agonists mediate their action by acting directly on the GLP-1R. Exenatide (Byetta ${ }^{\mathrm{TM}}$ ) was the first GLP-1R agonist to be prescribed for the treatment of T2DM and is a synthetic analog of the GLP-1R agonist, Ex-4. Ex-4 was originally isolated from the venom of Heloderma suspectum and shares 53\% sequence homology with native GLP-1 (Eng et al., 1992). Exenatide has a relatively short half-life, (60-90 min in humans, Kolterman et al., 2005) and is recommended for twice-daily administration. Liraglutide $\left(\right.$ Victoza $^{\mathrm{TM}}$ ) has $97 \%$ sequence homology with native GLP-1 and contains an Arg34Lys substitution as well as a glutamic acid and palmitic acid attached to Lys26. The addition of the fatty acid side chain to the peptide molecule allows for liraglutide to bind to albumin, which increases the time that the drug remains in circulation (Knudsen et al., 2000). The half-life for liraglutide is about $10-14 \mathrm{~h}$ in humans (Agerso et al., 2002) and is recommended for once-daily administration. Both exenatide (DeFronzo et al., 2005; Heine et al., 2005; Moretto et al., 2008; Norris et al., 2009) and liraglutide (Astrup et al., 2009; Garber et al., 2009; Niswender et al., 2013; Lean et al., 2014) significantly improve glycemic control and cause a significant body weight loss in T2DM patients. Gastrointestinal side effects including nausea and vomiting have been reported with both exenatide and liraglutide treatment although these side effects are often transient and occur mainly during the first few weeks of treatment in the dose escalation phase. A 26-week clinical study comparing the effectiveness of liraglutide (1.8 mg once-daily) with exenatide (10 $\mu \mathrm{g}$ twice-daily) indicates that patients treated with liraglutide had significantly greater reduction in $\mathrm{HbA1c}$ levels as well as significantly greater reduction in fasting plasma glucose levels as compared to patients treated with exenatide (Buse et al., 2009). However, both groups experienced similar levels of weight loss $(-3.24$ vs. $-2.87 \mathrm{~kg}$, liraglutide vs. exenatide).
A long-acting exenatide compound [exenatide extended release (ER; Bydureon ${ }^{\mathrm{TM}}$ )] was synthesized by encapsulating exenatide into microspheres of medical-grade poly- $(D, L$-lactide-coglycolide) which enables the drug to be released over an extended period of time (DeYoung et al., 2011). ER is recommended for once-weekly injection, which has major advantages in dealing patients who routinely forget to take their medication (Scott, 2012). The effects of ER once-weekly have been compared to exenatide twice-daily and overall ER was more effective at improving glycemic control and caused less gastrointestinal side-effects although both compounds caused a similar degree of weight loss (Drucker et al., 2008; Blevins et al., 2011).

The efficacy of once-weekly ER (2 mg) was compared to that of once-daily liraglutide $(1.8 \mathrm{mg})$ in a 26 -week trial in T2DM patients (Buse et al., 2013). Both treatments significantly improved glucose homeostasis and caused body weight reduction although liraglutide treated patients experienced a greater reduction in HbA1c levels, fasting serum glucose as well as a greater reduction in body weight as compared to ER. Adverse side effects including nausea, diarrhea and vomiting occurred more frequently in the liraglutide treated patients.

\section{DPP-4 Inhibitors}

The DPP-4 inhibitors mediate their action by inhibiting the enzyme DPP-4, which prevents the breakdown of GLP-1 and thereby increases endogenous GLP-1 levels. Sitagliptin (Aschner et al., 2006), saxagliptin (Rosenstock et al., 2009), and vildagliptin (Keating, 2010) all improve glucose metabolism in diabetic patients. One of the advantages of DPP-4 inhibitors is that patients rarely report nausea during treatment (Madsbad et al., 2008; Williams-Herman et al., 2010). However, unlike GLP-1R agonists, DPP-4 inhibitors do not cause significant reductions in body weight (Meneghini et al., 2011; Aroda et al., 2012). Taken together, GLP-1R agonists provide a superior advantage of reducing body weight in T2DM patients. However, T2DM patients with a lower tolerability for GLP-1R agonists may prefer treatment with DPP-4 inhibitors for the management of hyperglycemia.

\section{Novel GLP-1R Co-Therapies}

The GLP-1R agonists exenatide and liraglutide have promising effects on both glucose and energy homeostasis in T2DM patients. However, most effects on body weight are modest and tend to range between 2 to $4 \%$ body weight reduction (reviewed in Davidson, 2013). For obese individuals, there is a need for a more powerful weight loss option. By combining GLP-1R agonism with other methods of weight loss, overall weight reduction can be enhanced. Here, we review therapies that combine GLP1R pharmacotherapeutics with other weight loss mechanisms, which result in superior effects on body weight reduction and glucose metabolism.

\section{GLP-1R Agonism in Combination with the Adjustable Gastric Band}

Bariatric surgery is by far the most effective therapy for weight loss reduction and improvements in glucose metabolism 
(Pories, 2008). The two most effective bariatric procedures, Roux-en-Y gastric bypass (RYGB) and vertical sleeve gastrectomy (VSG) both result in enhanced meal-stimulated GLP-1 release which may be contributing to improvements in glucose metabolism and weight loss induced by these procedures. However, these types of bariatric surgery are very invasive and involve an irreversible manipulation of the gastrointestinal tract (reviewed in Stefater et al., 2012). A less invasive bariatric surgery is the adjustable gastric band (AGB), which involves placing an inflatable silicon band around the stomach near the esophageal junction. To modulate the degree of restriction, the band is inflated by infusing saline into a subcutaneously implanted port. Unfortunately, the AGB is far less effective on weight loss as compared to RYGB and VSG (Buchwald et al., 2009), which may be partially due to the fact that AGB does not enhance circulating GLP-1 levels (le Roux et al., 2006). A study in rats demonstrated that AGB can act synergistically with the GLP-1R agonist, Ex-4, to promote a more substantial weight loss as compared to Ex-4 treatment or AGB alone (Habegger et al., 2013). The advantage of this approach is that it combines two minimally invasive and reversible weight loss strategies, which in the future may provide patients with an alternative approach to weight loss.

\section{Single Molecule Multi-Agonists}

A number of metabolic hormones can achieve favorable effects on body weight loss but cannot be used as a weight loss therapeutic because of negative side effects. A new generation of pharmacotherapies have been developed which combine GLP-1R agonism with other metabolic hormones into a single molecule. This new line of pharmaceuticals maximizes the beneficial effects on energy and glucose metabolism while minimizing unwanted side-effects (Tschop and DiMarchi, 2012).

Glucagon $(\mathrm{Gcg})$ has many beneficial effects on energy homeostasis including the inhibition of food intake, as well as the ability to increase energy expenditure and activate BAT which all lead to a reduction in body weight (reviewed in Habegger et al., 2010; Heppner et al., 2010). The fact that Gcg causes an elevation in blood glucose levels in combination with its limited solubility at a physiological $\mathrm{pH}$ has discouraged the use of glucagon as a therapeutic for weight loss. Single molecules with GLP-1 and Gcg co-agonism were created to take advantage of the beneficial effects of both GLP-1 and Gcg on energy metabolism while limiting Gcg induction of hyperglycemia (Day et al., 2009; Pocai et al., 2009). Diet-induced obese (DIO) mice treated chronically with the GLP-1/Gcg coagonists lost significant body weight and fat mass and interestingly, also had improved glucose metabolism. However, Glp1r-/- mice treated with the GLP-1/Gcg coagonist experienced a reduction in body weight and fat mass but did not have improvements in glucose tolerance indicating that GLP$1 \mathrm{R}$ agonism is required to counteract the hyperglycemic effects of GcgR agonism (Day et al., 2009). The beneficial effects of single molecule GLP-1/Gcg coagonism were also demonstrated in ob/ob mice, which had enhanced GSIS and improved glucose tolerance upon acute treatment with a GLP-1/Gcg coagonist (Gault et al., 2013). To determine the site of action in the brain that GLP-1 and Gcg coagonism may be occurring, one group examined c-fos induction upon co-injection of GLP-1 and Gcg
(Parker et al., 2013). Doses of GLP-1 and Gcg that when administered alone did not affect food intake were given as a co-injection which resulted in a significant reduction in feeding and c-fos induction in both the area postrema and CeA. Whether the single molecule GLP-1/Gcg coagnonist has a similar CNS pattern of activation requires further investigation. Similar beneficial effects of GLP- $1 /$ Gcg coagonism on energy and glucose metabolism have been demonstrated in humans. Although not used in a single molecule, healthy human volunteers showed increased energy expenditure upon coinfusion of GLP-1 and Gcg, which was not apparent with GLP-1 infusion alone (Tan et al., 2013). Additionally, GLP-1/Gcg coinfusion limited the hyperglycemic action of Gcg (Tan et al., 2013). These data give a promising outlook that the enhanced effectiveness of GLP-1/Gcg coagnoism demonstrated in rodents will translate to enhanced weight loss in humans.

Glucose-dependent insulinotropic polypeptide (GIP) is an incretin hormone released from the K-cells of the small intestines and acts on the pancreas to potentiate GSIS (Miyawaki et al., 1999). Unlike, GLP-1 and Gcg, GIP is not derived from preproglucagon and does not cause a reduction in body weight (Baggio and Drucker, 2007). Interestingly, by combining GLP-1 and GIP agonism into a single molecule, the GIP/GLP-1 coagonist has enhanced therapeutic properties to improve glucose tolerance and induce weight loss, which was demonstrated in rodents, non-human primates and humans (Finan et al., 2013). Finally, a triagonist was synthesized to include GLP-1, Gcg, and GIP agonism (Finan et al., 2015). As compared to mono or coagonists, the triagonist had enhanced effectiveness to decrease body weight and fat mass in rodents. This effect was a result of a combination of a reduction in food intake and a shift in metabolic fuel preference to favor fat utilization.

An alternative approach aiming to maximize the efficacy of GLP-1 involves the delivery of nuclear receptor agonists to specific tissues characterized by the expression of GLP-1R. The superior efficacy of a single molecule combining GLP- 1 and estrogen receptor activity improving metabolic control supports the feasibility of this approach. Estrogen is a steroid hormone with beneficial effects in the control of energy balance (Brown and Clegg, 2010; Mauvais-Jarvis et al., 2013; Frank et al., 2014), however, these properties cannot be taken full advantage of because estrogen also acts as a carcinogen (Huang et al., 2014). By stably linking estrogen to GLP-1 in a single molecule, this coagonist can take advantage of estrogen's effects on weight loss while avoiding the negative side effects on other tissues (Finan et al., 2012). DIO ovariectomized female mice treated chronically with a stable estrogen/GLP-1 coagonist had significantly greater body weight and fat mass loss as compared to GLP-1R monagonists. Neither proliferation of the uterine lining nor tumor growth were detected in animals treated with the stable co-agonist indicating that the molecule was not having negative off target effects on peripheral tissue. The estrogen/GLP-1 coagonist loses its potency of action when administered to animals with a CNS specific deletion of the GLP-1R indicating that the GLP- $1 \mathrm{R}$ is essential for full effectiveness. The superior beneficial effects of GLP-1/estrogen co-agonism were also demonstrated in a mouse model prone to the development of diabetes, the New Zealand obese (NZO) 


\section{GLP-1R regulation of energy and glucose metabolism}

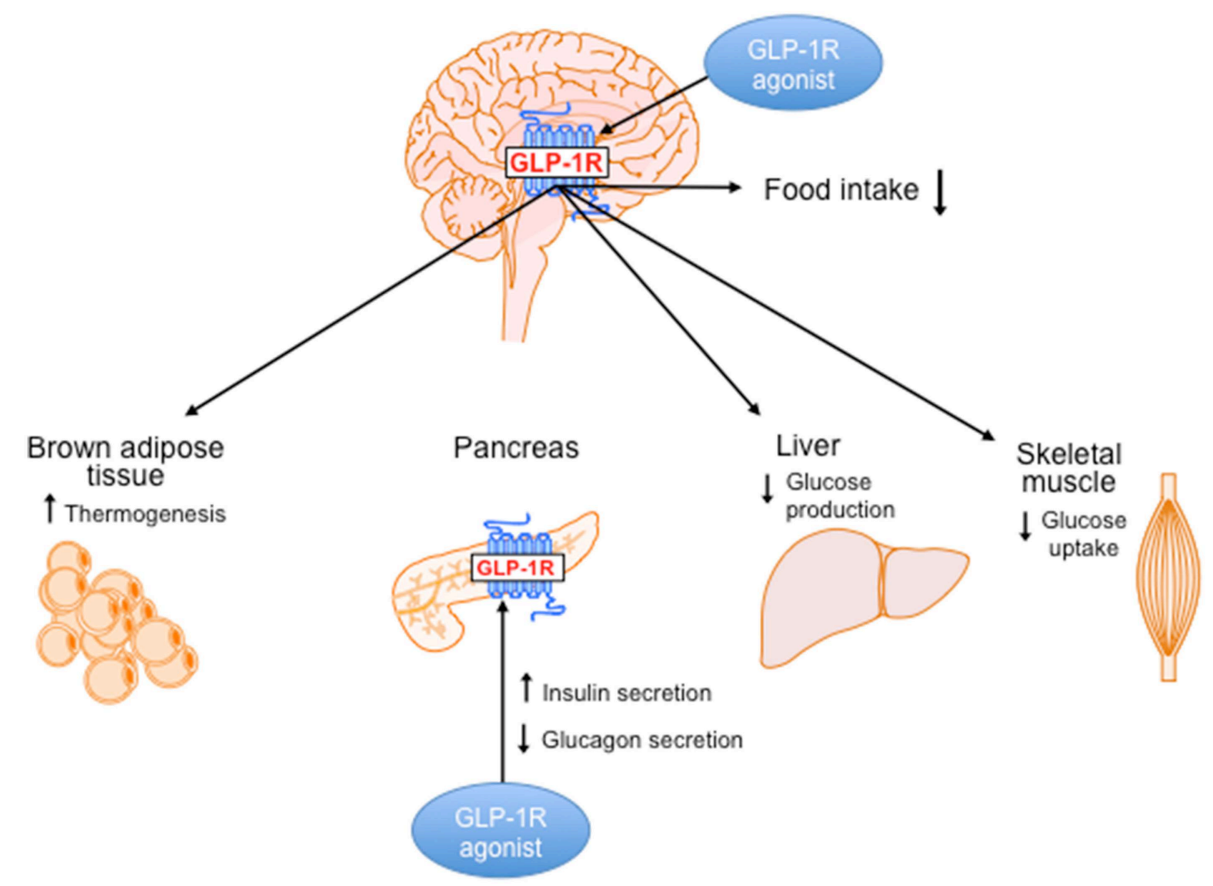

FIGURE 1 | GLP-1R signaling in the brain and periphery regulates energy and glucose metabolism. Body weight loss induced by GLP-1R agonism is controlled by CNS-mediated mechanisms and is mainly a result of a reduction in food intake. However, GLP-1R action in the brain activates brown adipose tissue thermogenesis, which may also

mouse. In contrast to GLP-1 mono-therapy, GLP-1/estrogen coagonism prevented hyperphagia and beta-cell failure in NZO mice (Schwenk et al., 2014). Taken together, the addition of other metabolic hormones to GLP-1R agonism results in superior effects on glucose and energy homeostasis.

\section{Conclusion}

In addition to the well-established role of GLP-1 to improve glucose homeostasis, GLP-1R agonism has beneficial effects on body weight reduction. The tissue-specific effects of GLP-1R signaling on energy and glucose and energy homeostasis are illustrated in Figure 1 and are divided into CNS vs. peripheral GLP-1Rmediated action. The fact that GLP-1R agonists have beneficial effects on both energy and glucose metabolism places this class of pharmacotherapies at a superior level compared to other drugs

\section{References}

Abbas, T., Faivre, E., and Holscher, C. (2009). Impairment of synaptic plasticity and memory formation in GLP-1 receptor KO mice: interaction between type 2 diabetes and Alzheimer's disease. Behav. Brain Res. 205, 265-271. doi: 10.1016/j.bbr.2009.06.035

Abbott, C. R., Monteiro, M., Small, C. J., Sajedi, A., Smith, K. L., Parkinson, J. R., et al. (2005). The inhibitory effects of peripheral administration of peptide YY(3-36) and glucagon-like peptide-1 on food intake are attenuated by ablation contribute to weight loss. In the brain, GLP-1R signaling regulates glucose homeostasis by decreasing hepatic glucose production and decreasing glucose uptake in muscle. In the periphery, GLP-1R agonists act directly on the pancreas to increase insulin secretion and reduce glucagon secretion.

used to treat T2DM that cause weight gain. Although physiological levels of GLP-1 can improve glycemic control, pharmacological levels of GLP-1 must be reached to promote weight loss. This is demonstrated by comparing the effects of DPP-4 inhibitors vs. GLP-1R agonists in T2DM patients. Both classes of drugs improve glycemic control in T2DM patients but only the GLP-1R agonists given at pharmacological doses will cause weight loss. However, the weight loss induced by GLP-1R monotherapies in obese T2DM patients is modest indicating a need for more robust therapeutic options. Pre-clinical data from studies that combine GLP-1R agonism with other weight loss strategies such as AGB or other metabolic hormones have highlighted more potent options for weight loss. Clinical testing of these combination therapies will be necessary to determine whether the effects translate to superior weight loss in obese T2DM patients. 
contributes to the control of food intake and motivation to feed. Neuropsychopharmacology 39, 2233-2243. doi: 10.1038/npp.2014.74

Aroda, V. R., Henry, R. R., Han, J., Huang, W., DeYoung, M. B., Darsow, T., et al. (2012). Efficacy of GLP-1 receptor agonists and DPP-4 inhibitors: meta-analysis and systematic review. Clin. Ther. 34, 1247.e22-1258.e22. doi: 10.1016/j.clinthera.2012.04.013

Aschner, P., Kipnes, M. S., Lunceford, J. K., Sanchez, M., Mickel, C., WilliamsHerman, D. E., et al. (2006). Effect of the dipeptidyl peptidase-4 inhibitor sitagliptin as monotherapy on glycemic control in patients with type 2 diabetes. Diabetes Care 29, 2632-2637. doi: 10.2337/dc06-0703

Astrup, A., Rossner, S., Van Gaal, L., Rissanen, A., Niskanen, L., Al Hakim, M., et al. (2009). Effects of liraglutide in the treatment of obesity: a randomised, double-blind, placebo-controlled study. Lancet 374, 1606-1616. doi: 10.1016/S0140-6736(09)61375-1

Ayala, J. E., Bracy, D. P., James, F. D., Julien, B. M., Wasserman, D. H., and Drucker, D. J. (2009). The glucagon-like peptide-1 receptor regulates endogenous glucose production and muscle glucose uptake independent of its incretin action. Endocrinology 150, 1155-1164. doi: 10.1210/en.2008-0945

Baggio, L. L., and Drucker, D. J. (2007). Biology of incretins: GLP-1 and GIP. Gastroenterology 132, 2131-2157. doi: 10.1053/j.gastro.2007.03.054

Barrera, J. G., Jones, K. R., Herman, J. P., D’Alessio, D. A., Woods, S. C., and Seeley, R. J. (2011b). Hyperphagia and increased fat accumulation in two models of chronic CNS glucagon-like peptide-1 loss of function. J. Neurosci. 31, 3904-3913. doi: 10.1523/JNEUROSCI.2212-10.2011

Barrera, J. G., Sandoval, D. A., D’Alessio, D. A., and Seeley, R. J. (2011a). GLP-1 and energy balance: an integrated model of short-term and long-term control. Nat Rev. Endocrinol. 7, 507-516. doi: 10.1038/nrendo.2011.77

Beiroa, D., Imbernon, M., Gallego, R., Senra, A., Herranz, D., Villaroya, F., et al. (2014). GLP-1 agonism stimulates brown adipose tissue thermogenesis and browning through hypothalamic AMPK. Diabetes. 63, 3346-3358. doi: $10.2337 / \mathrm{db} 14-0302$

Berkseth, K. E., Guyenet, S. J., Melhorn, S. J., Lee, D., Thaler, J. P., Schur, E. A., et al. (2014). Hypothalamic gliosis associated with high-fat diet feeding is reversible in mice: a combined immunohistochemical and magnetic resonance imaging study. Endocrinology 155, 2858-2867. doi: 10.1210/en.2014-1121

Bertilsson, G., Patrone, C., Zachrisson, O., Andersson, A., Dannaeus, K., Heidrich, J., et al. (2008). Peptide hormone exendin-4 stimulates subventricular zone neurogenesis in the adult rodent brain and induces recovery in an animal model of Parkinson's disease. J. Neurosci. Res. 86, 326-338. doi: 10.1002/jnr.21483

Blevins, T., Pullman, J., Malloy, J., Yan, P., Taylor, K., Schulteis, C., et al. (2011). DURATION-5: exenatide once weekly resulted in greater improvements in glycemic control compared with exenatide twice daily in patients with type 2 diabetes. J. Clin. Endocrinol. Metab. 96, 1301-1310. doi: 10.1210/jc.2010-2081

Bradley, D. P., Kulstad, R., Racine, N., Shenker, Y., Meredith, M., and Schoeller, D. A. (2012). Alterations in energy balance following exenatide administration. Appl. Physiol. Nutr. Metab. 37, 893-899. doi: 10.1139/h2012-068

Brown, L. M., and Clegg, D. J. (2010). Central effects of estradiol in the regulation of food intake, body weight, and adiposity. J. Steroid Biochem. Mol. Biol. 122, 65-73. doi: 10.1016/j.jsbmb.2009.12.005

Buchwald, H., Estok, R., Fahrbach, K., Banel, D., Jensen, M. D., Pories, W. J., et al. (2009). Weight and type 2 diabetes after bariatric surgery: systematic review and meta-analysis. Am. J. Med. 122, 248.e5-256.e5. doi: 10.1016/j.amjmed.2008.09.041

Bullock, B. P., Heller, R. S., and Habener, J. F. (1996). Tissue distribution of messenger ribonucleic acid encoding the rat glucagon-like peptide-1 receptor. Endocrinology 137, 2968-2978.

Burmeister, M. A., Ferre, T., Ayala, J. E., King, E. M., Holt, R. M., and Ayala, J. E. (2012). Acute activation of central GLP-1 receptors enhances hepatic insulin action and insulin secretion in high-fat-fed, insulin resistant mice. Am. J. Physiol. Endocrinol. Metab. 302, E334-E343. doi: 10.1152/ajpendo.00409.2011

Buse, J. B., Nauck, M., Forst, T., Sheu, W. H., Shenouda, S. K., Heilmann, C. R., et al. (2013). Exenatide once weekly versus liraglutide once daily in patients with type 2 diabetes (DURATION-6): a randomised, open-label study. Lancet 381, 117-124. doi: 10.1016/S0140-6736(12)61267-7

Buse, J. B., Rosenstock, J., Sesti, G., Schmidt, W. E., Montanya, E., Brett, J. H., et al. (2009). Liraglutide once a day versus exenatide twice a day for type 2 diabetes: a 26-week randomised, parallel-group, multinational, open-label trial (LEAD-6). Lancet 374, 39-47. doi: 10.1016/S0140-6736(09)60659-0
Campbell, J. E., and Drucker, D. J. (2013). Pharmacology, physiology, and mechanisms of incretin hormone action. Cell Metab. 17, 819-837. doi: 10.1016/j.cmet.2013.04.008

Challa, T. D., Beaton, N., Arnold, M., Rudofsky, G., Langhans, W., and Wolfrum, C. (2012). Regulation of adipocyte formation by GLP-1/GLP-1R signaling. J. Biol. Chem. 287, 6421-6430. doi: 10.1074/jbc.M111.310342

Dalvi, P. S., Nazarians-Armavil, A., Purser, M. J., and Belsham, D. D. (2012). Glucagon-like peptide-1 receptor agonist, exendin-4, regulates feedingassociated neuropeptides in hypothalamic neurons in vivo and in vitro. Endocrinology 153, 2208-2222. doi: 10.1210/en.2011-1795

Davidson, J. A. (2013). Incretin-based therapies: focus on effects beyond glycemic control alone. Diabetes Ther. 4, 221-238. doi: 10.1007/s13300-013-0040-0

Day, J. W., Ottaway, N., Patterson, J. T., Gelfanov, V., Smiley, D., Gidda, J., et al. (2009). A new glucagon and GLP-1 co-agonist eliminates obesity in rodents. Nat. Chem. Biol. 5, 749-757. doi: 10.1038/nchembio.209

Deacon, C. F., Nauck, M. A., Toft-Nielsen, M., Pridal, L., Willms, B., and Holst, J. J. (1995). Both subcutaneously and intravenously administered glucagon-like peptide I are rapidly degraded from the $\mathrm{NH}$-terminus in type II diabetic patients and in healthy subjects. Diabetes 44, 1126-1131. doi: 10.2337/diab.44.9.1126

DeFronzo, R. A., Ratner, R. E., Han, J., Kim, D. D., Fineman, M. S., and Baron, A. D. (2005). Effects of exenatide (exendin-4) on glycemic control and weight over 30 weeks in metformin-treated patients with type 2 diabetes. Diabetes Care 28, 1092-1100. doi: 10.2337/diacare.28.5.1092

DeYoung, M. B., MacConell, L., Sarin, V., Trautmann, M., and Herbert, P. (2011). Encapsulation of exenatide in poly-(D,L-lactide-co-glycolide) microspheres produced an investigational long-acting once-weekly formulation for type 2 diabetes. Diabetes Technol. Ther. 13, 1145-1154. doi: 10.1089/dia.2011.0050

Dickson, S. L., Shirazi, R. H., Hansson, C., Bergquist, F., Nissbrandt, H., and Skibicka, K. P. (2012). The glucagon-like peptide 1 (GLP-1) analogue, exendin4, decreases the rewarding value of food: a new role for mesolimbic GLP-1 receptors. J. Neurosci. 32, 4812-4820. doi: 10.1523/JNEUROSCI.6326-11.2012

Dossat, A. M., Lilly, N., Kay, K., and Williams, D. L. (2011). Glucagon-like peptide 1 receptors in nucleus accumbens affect food intake. J. Neurosci. 31, 14453-14457. doi: 10.1523/JNEUROSCI.3262-11.2011

Drucker, D. J., Buse, J. B., Taylor, K., Kendall, D. M., Trautmann, M., Zhuang, D., et al. (2008). Exenatide once weekly versus twice daily for the treatment of type 2 diabetes: a randomised, open-label, non-inferiority study. Lancet 372 , 1240-1250. doi: 10.1016/S0140-6736(08)61206-4

Drucker, D. J., and Nauck, M. A. (2006). The incretin system: glucagon-like peptide- 1 receptor agonists and dipeptidyl peptidase- 4 inhibitors in type 2 diabetes. Lancet 368, 1696-1705. doi: 10.1016/S0140-6736(06)69705-5

During, M. J., Cao, L., Zuzga, D. S., Francis, J. S., Fitzsimons, H. L., Jiao, X., et al. (2003). Glucagon-like peptide-1 receptor is involved in learning and neuroprotection. Nat. Med. 9, 1173-1179. doi: 10.1038/nm919

Eng, J., Kleinman, W. A., Singh, L., Singh, G., and Raufman, J. P. (1992). Isolation and characterization of exendin-4, an exendin-3 analogue, from Heloderma suspectum venom. Further evidence for an exendin receptor on dispersed acini from guinea pig pancreas. J. Biol. Chem. 267, 7402-7405.

Finan, B., Ma, T., Ottaway, N., Muller, T. D., Habegger, K. M., Heppner, K. M., et al. (2013). Unimolecular dual incretins maximize metabolic benefits in rodents, monkeys, and humans. Sci. Transl. Med. 5, 209ra151. doi: 10.1126/scitranslmed.3007218

Finan, B., Yang, B., Ottaway, N., Smiley, D. L., Ma, T., Clemmensen, C., et al. (2015). A rationally designed monomeric peptide triagonist corrects obesity and diabetes in rodents. Nat. Med. 21, 27-36. doi: 10.1038/nm.3761

Finan, B., Yang, B., Ottaway, N., Stemmer, K., Muller, T. D., Yi, C. X., et al. (2012). Targeted estrogen delivery reverses the metabolic syndrome. Nat. Med. 18, 1847-1856. doi: 10.1038/nm.3009

Finkelstein, E. A., Trogdon, J. G., Cohen, J. W., and Dietz, W. (2009). Annual medical spending attributable to obesity: payer-and service-specific estimates. Health Aff. 28, w822-w831. doi: 10.1377/hlthaff.28.5.w822

Fontaine, K. R., Redden, D. T., Wang, C., Westfall, A. O., and Allison, D. B. (2003). Years of life lost due to obesity. JAMA 289, 187-193. doi: 10.1001/jama.289.2.187

Frank, A., Brown, L. M., and Clegg, D. J. (2014). The role of hypothalamic estrogen receptors in metabolic regulation. Front. Neuroendocrinol. 35, 550-557. doi: 10.1016/j.yfrne.2014.05.002 
Garber, A., Henry, R., Ratner, R., Garcia-Hernandez, P. A., Rodriguez-Pattzi, H., Olvera-Alvarez, I., et al. (2009). Liraglutide versus glimepiride monotherapy for type 2 diabetes (LEAD-3 Mono): a randomised, 52-week, phase III, double-blind, parallel-treatment trial. Lancet 373, 473-481. doi: 10.1016/S01406736(08)61246-5

Gault, V. A., Bhat, V. K., Irwin, N., and Flatt, P. R. (2013). A novel glucagon-like peptide-1 (GLP-1)/glucagon hybrid peptide with triple-acting agonist activity at glucose-dependent insulinotropic polypeptide, GLP-1, and glucagon receptors and therapeutic potential in high fat-fed mice. J. Biol. Chem. 288, 35581-35591. doi: 10.1074/jbc.M113.512046

Habegger, K. M., Heppner, K. M., Geary, N., Bartness, T. J., DiMarchi, R., and Tschop, M. H. (2010). The metabolic actions of glucagon revisited. Nat. Rev. Endocrinol. 6, 689-697. doi: 10.1038/nrendo.2010.187

Habegger, K. M., Kirchner, H., Yi, C. X., Heppner, K. M., Sweeney, D., Ottaway, N., et al. (2013). GLP-1R agonism enhances adjustable gastric banding in diet-induced obese rats. Diabetes 62, 3261-3267. doi: 10.2337/db13-0117

Han, W. N., Holscher, C., Yuan, L., Yang, W., Wang, X. H., Wu, M. N., et al. (2013). Liraglutide protects against amyloid-beta protein-induced impairment of spatial learning and memory in rats. Neurobiol. Aging 34, 576-588. doi: 10.1016/j.neurobiolaging.2012.04.009

Hansen, G., Jelsing, J., and Vrang, N. (2012). Effects of liraglutide and sibutramine on food intake, palatability, body weight and glucose tolerance in the gubra DIO-rats. Acta Pharmacol. Sin. 33, 194-200. doi: 10.1038/aps.2011.168

Hansotia, T., Maida, A., Flock, G., Yamada, Y., Tsukiyama, K., Seino, Y., et al. (2007). Extrapancreatic incretin receptors modulate glucose homeostasis, body weight, and energy expenditure. J. Clin. Invest. 117, 143-152. doi: $10.1172 /$ JCI25483

Harder, H., Nielsen, L., Tu, D. T., and Astrup, A. (2004). The effect of liraglutide, a long-acting glucagon-like peptide 1 derivative, on glycemic control, body composition, and 24-h energy expenditure in patients with type 2 diabetes. Diabetes Care 27, 1915-1921. doi: 10.2337/diacare.27.8.1915

Harkavyi, A., Abuirmeileh, A., Lever, R., Kingsbury, A. E., Biggs, C. S., and Whitton, P. S. (2008). Glucagon-like peptide 1 receptor stimulation reverses key deficits in distinct rodent models of Parkinson's disease. J. Neuroinflammation 5:19. doi: 10.1186/1742-2094-5-19

Hayes, M. R., Leichner, T. M., Zhao, S., Lee, G. S., Chowansky, A., Zimmer, D., et al. (2011). Intracellular signals mediating the food intake-suppressive effects of hindbrain glucagon-like peptide-1 receptor activation. Cell Metab. 13, 320-330. doi: 10.1016/j.cmet.2011.02.001

Heine, R. J., Van Gaal, L. F., Johns, D., Mihm, M. J., Widel, M. H., Brodows, R. G., et al. (2005). Exenatide versus insulin glargine in patients with suboptimally controlled type 2 diabetes: a randomized trial. Ann. Intern. Med. 143, 559-569. doi: 10.7326/0003-4819-143-8-200510180-00006

Heppner, K. M., Habegger, K. M., Day, J., Pfluger, P. T., Perez-Tilve, D., Ward, B., et al. (2010). Glucagon regulation of energy metabolism. Physiol. Behav. 100, 545-548. doi: 10.1016/j.physbeh.2010.03.019

Heppner, K. M., Kirigiti, M., Secher, A., Paulsen, S. J., Buckingham, R., Pyke, C., et al. (2015). Expression and distribution of glucagon-like peptide1 receptor mRNA, protein and binding in the male nonhuman primate (Macaca mulatta) brain. Endocrinology. 156, 255-267. doi: 10.1210/en.20141675

Holscher, C. (2014). Central effects of GLP-1: new opportunities for treatments of neurodegenerative diseases. J. Endocrinol. 221, T31-T41. doi: 10.1530/JOE-130221

Holst, J. J. (2007). The physiology of glucagon-like peptide 1. Physiol. Rev. 87, 1409-1439. doi: 10.1152/physrev.00034.2006

Home, P. D., Pocock, S. J., Beck-Nielsen, H., Curtis, P. S., Gomis, R., Hanefeld, M., et al. (2009). Rosiglitazone evaluated for cardiovascular outcomes in oral agent combination therapy for type 2 diabetes (RECORD): a multicentre, randomised, open-label trial. Lancet 373, 2125-2135. doi: 10.1016/S01406736(09)60953-3

Huang, B., Warner, M., and Gustafsson, J. A. (2014). Estrogen receptors in breast carcinogenesis and endocrine therapy. Mol. Cell. Endocrinol. doi: 10.1016/j.mce.2014.11.015. [Epub ahead of print].

Jin, S. L., Han, V. K., Simmons, J. G., Towle, A. C., Lauder, J. M., and Lund, P. K. (1988). Distribution of glucagonlike peptide I (GLP-I), glucagon, and glicentin in the rat brain: an immunocytochemical study. J. Comp. Neurol. 271, 519-532. doi: $10.1002 /$ cne. 902710405
Kahn, S. E., Haffner, S. M., Heise, M. A., Herman, W. H., Holman, R. R., Jones, N. P., et al. (2006). Glycemic durability of rosiglitazone, metformin, or glyburide monotherapy. N. Engl. J. Med. 355, 2427-2443. doi: 10.1056/NEJMoa066224

Kanoski, S. E., Fortin, S. M., Arnold, M., Grill, H. J., and Hayes, M. R. (2011). Peripheral and central GLP-1 receptor populations mediate the anorectic effects of peripherally administered GLP-1 receptor agonists, liraglutide and exendin-4. Endocrinology 152, 3103-3112. doi: 10.1210/en.2011-0174

Kanoski, S. E., Rupprecht, L. E., Fortin, S. M., De Jonghe, B. C., and Hayes, M. R. (2012). The role of nausea in food intake and body weight suppression by peripheral GLP-1 receptor agonists, exendin-4 and liraglutide. Neuropharmacology 62, 1916-1927. doi: 10.1016/j.neuropharm.2011.12.022

Keating, G. M. (2010). Vildagliptin: a review of its use in type 2 diabetes mellitus. Drugs 70, 2089-2112. doi: 10.2165/11206370-000000000-00000

Kinzig, K. P., D’Alessio, D. A., and Seeley, R. J. (2002). The diverse roles of specific GLP-1 receptors in the control of food intake and the response to visceral illness. J. Neurosci. 22, 10470-10476.

Kirkpatrick, A., Heo, J., Abrol, R., and Goddard, W. A. III. (2012). Predicted structure of agonist-bound glucagon-like peptide 1 receptor, a class B G protein-coupled receptor. Proc. Natl. Acad. Sci. U.S.A. 109, 19988-19993. doi: 10.1073/pnas.1218051109

Klein, S., Sheard, N. F., Pi-Sunyer, X., Daly, A., Wylie-Rosett, J., Kulkarni, K., et al. (2004). Weight management through lifestyle modification for the prevention and management of type 2 diabetes: rationale and strategies: a statement of the American Diabetes Association, the North American Association for the Study of Obesity, and the American Society for Clinical Nutrition. Diabetes Care 27, 2067-2073. doi: 10.2337/diacare.27.8.2067

Knauf, C., Cani, P. D., Perrin, C., Iglesias, M. A., Maury, J. F., Bernard, E., et al. (2005). Brain glucagon-like peptide-1 increases insulin secretion and muscle insulin resistance to favor hepatic glycogen storage. J. Clin. Invest. 115, 3554-3563. doi: 10.1172/JCI25764

Knudsen, L. B., Nielsen, P. F., Huusfeldt, P. O., Johansen, N. L., Madsen, K., Pedersen, F. Z., et al. (2000). Potent derivatives of glucagon-like peptide-1 with pharmacokinetic properties suitable for once daily administration. J. Med. Chem. 43, 1664-1669. doi: 10.1021/jm9909645

Kolterman, O. G., Kim, D. D., Shen, L., Ruggles, J. A., Nielsen, L. L., Fineman, M. S., et al. (2005). Pharmacokinetics, pharmacodynamics, and safety of exenatide in patients with type 2 diabetes mellitus. Am. J. Health Syst. Pharm. 62, 173-181.

Komatsu, R., Matsuyama, T., Namba, M., Watanabe, N., Itoh, H., Kono, N., et al. (1989). Glucagonostatic and insulinotropic action of glucagonlike peptide I-(7-36)-amide. Diabetes 38, 902-905. doi: 10.2337/diab.38.7.902

Kreisler, A. D., Davis, E. A., and Rinaman, L. (2014). Differential activation of chemically identified neurons in the caudal nucleus of the solitary tract in nonentrained rats after intake of satiating vs. non-satiating meals. Physiol. Behav. 136, 47-54. doi: 10.1016/j.physbeh.2014.01.015

Kreymann, B., Williams, G., Ghatei, M. A., and Bloom, S. R. (1987). Glucagonlike peptide-1 7-36: a physiological incretin in man. Lancet 2, 1300-1304. doi: 10.1016/S0140-6736(87)91194-9

Lamont, B. J., Li, Y., Kwan, E., Brown, T. J., Gaisano, H., and Drucker, D. J. (2012). Pancreatic GLP-1 receptor activation is sufficient for incretin control of glucose metabolism in mice. J. Clin. Invest. 122, 388-402. doi: 10.1172/JCI42497

Lean, M. E., Carraro, R., Finer, N., Hartvig, H., Lindegaard, M. L., Rossner, S., et al. (2014). Tolerability of nausea and vomiting and associations with weight loss in a randomized trial of liraglutide in obese, non-diabetic adults. Int. J. Obes. 38, 689-697. doi: 10.1038/ijo.2013.149

le Roux, C. W., Aylwin, S. J., Batterham, R. L., Borg, C. M., Coyle, F., Prasad, V., et al. (2006). Gut hormone profiles following bariatric surgery favor an anorectic state, facilitate weight loss, and improve metabolic parameters. Ann. Surg. 243, 108-114. doi: 10.1097/01.sla.0000183349.16877.84

Li, Y., Perry, T., Kindy, M. S., Harvey, B. K., Tweedie, D., Holloway, H. W., et al. (2009). GLP-1 receptor stimulation preserves primary cortical and dopaminergic neurons in cellular and rodent models of stroke and Parkinsonism. Proc. Natl. Acad. Sci. U.S.A. 106, 1285-1290. doi: 10.1073/pnas.0806720106

Lockie, S. H., Heppner, K. M., Chaudhary, N., Chabenne, J. R., Morgan, D. A., Veyrat-Durebex, C., et al. (2012). Direct control of brown adipose tissue thermogenesis by central nervous system glucagon-like peptide-1 receptor signaling. Diabetes 61, 2753-2762. doi: 10.2337/db11-1556

Lockie, S. H., Stefanidis, A., Oldfield, B. J., and Perez-Tilve, D. (2013). Brown adipose tissue thermogenesis in the resistance to and reversal of obesity: a potential 
new mechanism contributing to the metabolic benefits of proglucagon-derived peptides. Adipocyte 2, 196-200. doi: 10.4161/adip.25417

Madsbad, S. (2014). The role of glucagon-like peptide-1 impairment in obesity and potential therapeutic implications. Diabetes Obes. Metab. 16, 9-21. doi: 10.1111/dom.12119

Madsbad, S., Krarup, T., Deacon, C. F., and Holst, J. J. (2008). Glucagon-like peptide receptor agonists and dipeptidyl peptidase- 4 inhibitors in the treatment of diabetes: a review of clinical trials. Curr. Opin. Clin. Nutr. Metab. Care 11, 491-499. doi: 10.1097/MCO.0b013e328302f414

Mauvais-Jarvis, F., Clegg, D. J., and Hevener, A. L. (2013). The role of estrogens in control of energy balance and glucose homeostasis. Endocr. Rev. 34, 309-338. doi: 10.1210/er.2012-1055

McClean, P. L., Gault, V. A., Harriott, P., and Holscher, C. (2010). Glucagonlike peptide-1 analogues enhance synaptic plasticity in the brain: a link between diabetes and Alzheimer's disease. Eur. J. Pharmacol. 630, 158-162. doi: 10.1016/j.ejphar.2009.12.023

McClean, P. L., Parthsarathy, V., Faivre, E., and Holscher, C. (2011). The diabetes drug liraglutide prevents degenerative processes in a mouse model of Alzheimer's disease. J. Neurosci. 31, 6587-6594. doi: 10.1523/JNEUROSCI.0529-11.2011

McIntyre, R. S., Powell, A. M., Kaidanovich-Beilin, O., Soczynska, J. K., Alsuwaidan, M., Woldeyohannes, H. O., et al. (2013). The neuroprotective effects of GLP-1: possible treatments for cognitive deficits in individuals with mood disorders. Behav. Brain Res. 237, 164-171. doi: 10.1016/j.bbr.2012.09.021

McMahon, L. R., and Wellman, P. J. (1998). PVN infusion of GLP-1-(7-36) amide suppresses feeding but does not induce aversion or alter locomotion in rats. Am. J. Physiol. 274, R23-R29.

Meneghini, L. F., Orozco-Beltran, D., Khunti, K., Caputo, S., Damci, T., Liebl, A., et al. (2011). Weight beneficial treatments for type 2 diabetes. J. Clin. Endocrinol. Metab. 96, 3337-3353. doi: 10.1210/jc.2011-1074

Merchenthaler, I., Lane, M., and Shughrue, P. (1999). Distribution of pre-proglucagon and glucagon-like peptide-1 receptor messenger RNAs in the rat central nervous system. J. Comp. Neurol. 403, 261-280.

Miyawaki, K., Yamada, Y., Yano, H., Niwa, H., Ban, N., Ihara, Y., et al. (1999). Glucose intolerance caused by a defect in the entero-insular axis: a study in gastric inhibitory polypeptide receptor knockout mice. Proc. Natl. Acad. Sci. U.S.A. 96, 14843-14847. doi: 10.1073/pnas.96.26.14843

Mojsov, S., Weir, G. C., and Habener, J. F. (1987). Insulinotropin: glucagon-like peptide I (7-37) co-encoded in the glucagon gene is a potent stimulator of insulin release in the perfused rat pancreas. J. Clin. Invest. 79, 616-619. doi: 10.1172/JCI112855

Moretto, T. J., Milton, D. R., Ridge, T. D., Macconell, L. A., Okerson, T., Wolka, A. M., et al. (2008). Efficacy and tolerability of exenatide monotherapy over 24 weeks in antidiabetic drug-naive patients with type 2 diabetes: a randomized, double-blind, placebo-controlled, parallel-group study. Clin. Ther. 30, 1448-1460. doi: 10.1016/j.clinthera.2008.08.006

Niswender, K., Pi-Sunyer, X., Buse, J., Jensen, K. H., Toft, A. D., Russell-Jones, D., et al. (2013). Weight change with liraglutide and comparator therapies: an analysis of seven phase 3 trials from the liraglutide diabetes development programme. Diabetes Obes. Metab. 15, 42-54. doi: 10.1111/j.14631326.2012.01673.x

Norris, S. L., Lee, N., Thakurta, S., and Chan, B. K. (2009). Exenatide efficacy and safety: a systematic review. Diabet. Med. 26, 837-846. doi: 10.1111/j.14645491.2009.02790.x

Oka, J. I., Goto, N., and Kameyama, T. (1999). Glucagon-like peptide-1 modulates neuronal activity in the rat's hippocampus. Neuroreport 10, 1643-1646. doi: 10.1097/00001756-199906030-00004

Olshansky, S. J., Passaro, D. J., Hershow, R. C., Layden, J., Carnes, B. A., Brody, J., et al. (2005). A potential decline in life expectancy in the United States in the 21st century. N. Engl. J. Med. 352, 1138-1145. doi: 10.1056/NEJMsr043743

Parker, J. A., McCullough, K. A., Field, B. C., Minnion, J. S., Martin, N. M., Ghatei, M. A., et al. (2013). Glucagon and GLP-1 inhibit food intake and increase c-fos expression in similar appetite regulating centres in the brainstem and amygdala. Int. J. Obes. 37, 1391-1398. doi: 10.1038/ijo.2012.227

Perez-Tilve, D., Gonzalez-Matias, L., Aulinger, B. A., Alvarez-Crespo, M., GilLozano, M., Alvarez, E., et al. (2010). Exendin-4 increases blood glucose levels acutely in rats by activation of the sympathetic nervous system. Am. J. Physiol. Endocrinol. Metab. 298, E1088-E1096. doi: 10.1152/ajpendo.00464.2009
Pocai, A., Carrington, P. E., Adams, J. R., Wright, M., Eiermann, G., Zhu, L., et al. (2009). Glucagon-like peptide 1/glucagon receptor dual agonism reverses obesity in mice. Diabetes 58, 2258-2266. doi: 10.2337/db09-0278

Pories, W. J. (2008). Bariatric surgery: risks and rewards. J. Clin. Endocrinol. Metab. 93, S89-S96. doi: 10.1210/jc.2008-1641

Pyke, C., Heller, R. S., Kirk, R. K., Orskov, C., Reedtz-Runge, S., Kaastrup, P., et al. (2014). GLP-1 receptor localization in monkey and human tissue; Novel distribution revealed with extensively validated monoclonal antibody. Endocrinology. 155, 1280-1290. doi: 10.1210/en.2013-1934

Raun, K., von Voss, P., Gotfredsen, C. F., Golozoubova, V., Rolin, B., and Knudsen, L. B. (2007). Liraglutide, a long-acting glucagonlike peptide-1 analog, reduces body weight and food intake in obese candy-fed rats, whereas a dipeptidyl peptidase-IV inhibitor, vildagliptin, does not. Diabetes 56, 8-15. doi: 10.2337/db060565

Ronnekleiv, O. K., Fang, Y., Zhang, C., Nestor, C. C., Mao, P., and Kelly, M. J. (2014). Research resource: gene profiling of $G$ protein-coupled receptors in the arcuate nucleus of the female. Mol. Endocrinol. 28, 1362-1380. doi: 10.1210/me.2014-1103

Rosenstock, J., Aguilar-Salinas, C., Klein, E., Nepal, S., List, J., Chen, R., et al. (2009). Effect of saxagliptin monotherapy in treatment-naive patients with type 2 diabetes. Curr. Med. Res. Opin. 25, 2401-2411. doi: 10.1185/03007990903178735

Ryan, K. K., Li, B., Grayson, B. E., Matter, E. K., Woods, S. C., and Seeley, R. J. (2011). A role for central nervous system PPAR-gamma in the regulation of energy balance. Nat. Med. 17, 623-626. doi: 10.1038/nm.2349

Sandoval, D. A., Bagnol, D., Woods, S. C., D’Alessio, D. A., and Seeley, R. J. (2008). Arcuate glucagon-like peptide 1 receptors regulate glucose homeostasis but not food intake. Diabetes 57, 2046-2054. doi: 10.2337/db07-1824

Schwenk, R. W., Baumeier, C., Finan, B., Kluth, O., Brauer, C., Joost, H. G., et al. (2014). GLP-1-oestrogen attenuates hyperphagia and protects from beta cell failure in diabetes-prone New Zealand obese (NZO) mice. Diabetologia. 58, 604-614. doi: 10.1007/s00125-014-3478-3

Scott, L. J. (2012). Exenatide extended-release: a review of its use in type 2 diabetes mellitus. Drugs 72, 1679-1707. doi: 10.2165/11209750-000000000-00000

Scrocchi, L. A., Brown, T. J., MaClusky, N., Brubaker, P. L., Auerbach, A. B., Joyner, A. L., et al. (1996). Glucose intolerance but normal satiety in mice with a null mutation in the glucagon-like peptide 1 receptor gene. Nat. Med. 2, 1254-1258. doi: 10.1038/nm1196-1254

Secher, A., Jelsing, J., Baquero, A. F., Hecksher-Sorensen, J., Cowley, M. A., Dalboge, L. S., et al. (2014). The arcuate nucleus mediates GLP-1 receptor agonist liraglutide-dependent weight loss. J. Clin. Invest. 124, 4473-4488. doi: 10.1172/JCI75276

Seeley, R. J., Blake, K., Rushing, P. A., Benoit, S., Eng, J., Woods, S. C., et al. (2000). The role of CNS glucagon-like peptide-1 (7-36) amide receptors in mediating the visceral illness effects of lithium chloride. J. Neurosci. 20, 1616-1621.

Seo, S., Ju, S., Chung, H., Lee, D., and Park, S. (2008). Acute effects of glucagon-like peptide-1 on hypothalamic neuropeptide and AMP activated kinase expression in fasted rats. Endocr. J. 55, 867-874. doi: 10.1507/endocrj.K08E-091

Sisley, S., Gutierrez-Aguilar, R., Scott, M., D’Alessio, D. A., Sandoval, D. A., and Seeley, R. J. (2014). Neuronal GLP1R mediates liraglutide's anorectic but not glucose-lowering effect. J. Clin. Invest. 124, 2456-2463. doi: 10.1172/JCI72434

Smith, E. P., An, Z., Wagner, C., Lewis, A. G., Cohen, E. B., Li, B., et al. (2014). The role of beta cell glucagon-like peptide-1 signaling in glucose regulation and response to diabetes drugs. Cell Metab. 19, 1050-1057. doi: 10.1016/j.cmet.2014.04.005

Stefater, M. A., Wilson-Perez, H. E., Chambers, A. P., Sandoval, D. A., and Seeley, R. J. (2012). All bariatric surgeries are not created equal: insights from mechanistic comparisons. Endocr. Rev. 33, 595-622. doi: 10.1210/er.2011-1044

Tan, T. M., Field, B. C., McCullough, K. A., Troke, R. C., Chambers, E. S., Salem, V., et al. (2013). Coadministration of glucagon-like peptide-1 during glucagon infusion in humans results in increased energy expenditure and amelioration of hyperglycemia. Diabetes 62, 1131-1138. doi: 10.2337/db12-0797

Tang-Christensen, M., Vrang, N., and Larsen, P. J. (1998). Glucagon-like peptide 1(7-36) amide's central inhibition of feeding and peripheral inhibition of drinking are abolished by neonatal monosodium glutamate treatment. Diabetes 47, 530-537. doi: 10.2337/diabetes. 47.4 .530 
Thorens, B. (1992). Expression cloning of the pancreatic beta cell receptor for the gluco-incretin hormone glucagon-like peptide 1. Proc. Natl. Acad. Sci. U.S.A. 89, 8641-8645. doi: 10.1073/pnas.89.18.8641

Thule, P. M., and Umpierrez, G. (2014). Sulfonylureas: a new look at old therapy. Curr. Diab. Rep. 14, 473. doi: 10.1007/s11892-014-0473-5

Tschop, M. H., and DiMarchi, R. D. (2012). Outstanding scientific achievement award lecture 2011: defeating diabesity: the case for personalized combinatorial therapies. Diabetes 61, 1309-1314. doi: 10.2337/db12-0272

Turton, M. D., O'Shea, D., Gunn, I., Beak, S. A., Edwards, C. M., Meeran, K., et al. (1996). A role for glucagon-like peptide-1 in the central regulation of feeding. Nature 379, 69-72. doi: 10.1038/379069a0

Vahl, T. P., Tauchi, M., Durler, T. S., Elfers, E. E., Fernandes, T. M., Bitner, R. D., et al. (2007). Glucagon-like peptide-1 (GLP-1) receptors expressed on nerve terminals in the portal vein mediate the effects of endogenous GLP-1 on glucose tolerance in rats. Endocrinology 148, 4965-4973. doi: 10.1210/en. 2006-0153

van Bloemendaal, L., IJzerman, R. G., Ten Kulve, J. S., Barkhof, F., Konrad, R. J., Drent, M. L., et al. (2014). GLP-1 receptor activation modulates appetiteand reward-related brain areas in humans. Diabetes. 63, 4186-4196. doi: $10.2337 / \mathrm{db} 14-0849$

van Can, J., Sloth, B., Jensen, C. B., Flint, A., Blaak, E. E., and Saris, W. H. (2014). Effects of the once-daily GLP-1 analog liraglutide on gastric emptying, glycemic parameters, appetite and energy metabolism in obese, non-diabetic adults. Int. J. Obes. 38, 784-793. doi: 10.1038/ijo.2013.162

Vrang, N., and Grove, K. (2011). The brainstem preproglucagon system in a non-human primate (Macaca mulatta). Brain Res. 1397, 28-37. doi: 10.1016/j.brainres.2011.05.002

Wan, S., Coleman, F. H., and Travagli, R. A. (2007). Glucagon-like peptide-1 excites pancreas-projecting preganglionic vagal motoneurons. Am. J. Physiol. Gastrointest. Liver Physiol. 292, G1474-G1482. doi: 10.1152/ajpgi.00562.2006
Willard, F. S., and Sloop, K. W. (2012). Physiology and emerging biochemistry of the glucagon-like peptide-1 receptor. Exp. Diabetes Res. 2012:470851. doi: $10.1155 / 2012 / 470851$

Williams-Herman, D., Engel, S. S., Round, E., Johnson, J., Golm, G. T., Guo, H., et al. (2010). Safety and tolerability of sitagliptin in clinical studies: a pooled analysis of data from 10,246 patients with type 2 diabetes. BMC Endocr. Disord. 10:7. doi: 10.1186/1472-6823-10-7

Wilson-Perez, H. E., Chambers, A. P., Ryan, K. K., Li, B., Sandoval, D. A., Stoffers, D., et al. (2013). Vertical sleeve gastrectomy is effective in two genetic mouse models of glucagon-like Peptide 1 receptor deficiency. Diabetes 62, 2380-2385. doi: $10.2337 / \mathrm{db} 12-1498$

Wing, R. R., Lang, W., Wadden, T. A., Safford, M., Knowler, W. C., Bertoni, A. G., et al. (2011). Benefits of modest weight loss in improving cardiovascular risk factors in overweight and obese individuals with type 2 diabetes. Diabetes Care 34, 1481-1486. doi: 10.2337/dc10-2415

Zheng, H., Cai, L., and Rinaman, L. (2015). Distribution of glucagon-like peptide 1-immunopositive neurons in human caudal medulla. Brain Struc. Funct. 220, 1213-1219. doi: 10.1007/s00429-014-0714-z

Conflict of Interest Statement: The authors declare that the research was conducted in the absence of any commercial or financial relationships that could be construed as a potential conflict of interest.

Copyright (C) 2015 Heppner and Perez-Tilve. This is an open-access article distributed under the terms of the Creative Commons Attribution License (CC BY). The use, distribution or reproduction in other forums is permitted, provided the original author(s) or licensor are credited and that the original publication in this journal is cited, in accordance with accepted academic practice. No use, distribution or reproduction is permitted which does not comply with these terms. 